\title{
Effects of a low dietary linoleic acid level on intestinal morphology and enterocyte brush border membrane lipid composition
}

\author{
R Christon *, JC Meslin, J Thévenoux, \\ A Linard, CL Léger, S Delpal
}

INRA, Laboratoire de Nutrition et Sécurité Alimentaire, 78352 Jouy-en-Josas Cedex, France

(Received 4 July 1991; accepted 17 September 1991)

\begin{abstract}
Summary - The influence of low dietary linoleic acid level (an essential fatty acid deficiency) on the intestine mucosal morphology and the purified brush border membrane (BBM) lipid composition was investigated in the rat. Electron micrographs and morphometric measurements showed that villi and crypt sizes as well as the ultrastructure of epithelial cells were altered. Cholesterol (CHOL) and phospholipid (PL) levels, CHOL/PL ratio and PL class distribution were not changed by the low linoleate diet. However, the fatty acid composition of phospholipids was markedly modified in the enterocyte BBM, showing elevated amounts of palmitoleic (16:1n-7), oleic (18:1n-9) and $5,8,11-$ eicosatrienoic (20:3n-9) acids and, by contrast, depressed linoleic (18:2n-6) and arachidonic $(20: 4 n-6)$ acid levels. Although the underlying mechanisms remain unknown the results obtained suggest that essential fatty acids (EFA) could be directly involved in the trigger action of the observed alterations, as regards both their dynamic (metabolic) and structural roles.
\end{abstract}

essential fatty acid / Intestinal morphology / brush border membrane / llpid composition / rat

Résumé - Effets d'un régime pauvre en acide linoléique sur la morphologie intestinale et la composition lipidique de la bordure en brosse entérocytaire. L'influence d'un faible apport alimentaire d'acide linoléique (équivalant en fait à une déficience en acides gras essentiels) sur la morphologie de la muqueuse intestinale et la composition lipidique de la bordure en brosse purifiée a été étudiée chez le rat. L'observation en microscopie électronique à balayage et à transmission ainsi que l'étude morphométrique montrent que la taille des villosités et des cryptes, aussi bien que l'ultrastructure des cellules épithéliales, sont modifiées par la déficience nutritionnelle. Les teneurs en cholestérol (CHOL) et en phospholipides (PL), le rapport CHOL/PL, ainsi que la répartition en classes de $P L$, demeurent inchangés. En revanche, la composition en acides gras des PL est profondément modifiée, montrant notamment un accroissement des concentrations d'acides palmitoléique (16:1n-7), oléqque (18:1n-9), eicosatriénoïque (20:3n-9) et, au contraire, une diminution des teneurs en acides linoléique (18:2n-6) et arachidonique (20:4n-6). Les résultats obtenus suggèrent, quoique les mécanismes mis en jeu demeurent inconnus, que les acides gras essentiels pourraient être directement impliqués dans le diclenchement des modifications observées, à la fois par leur fonction métabolique et leur rôle structural.

acide gras essentiel / morphologie Intestinale / lipide membranaire / bordure en brosse entérocytaire / rat

* Correspondence and reprints 


\section{INTRODUCTION}

It has been clearly demonstrated that dietary fat can alter the intestinal mucosa (Hart et al, 1988), particularly its lipid composition (Yurkowski and Walker, 1970). Moreover, a diet rich in non-essential fatty acids leads to lower villus height, width, thickness, and density (Thomson et al, 1986), and an essential fatty acid (EFA)deficient diet is associated with increased cell proliferation in the gastrointestinal epithelium (Eynard et al, 1982). EFA deficiency was also accompanied by an incomplete differentiation of epithelial cells from the crypts, associated with structural and functional alteration of jejunal differentiated cells (Snipes, 1967a). This latter fact was correlated with a decreased fat absorption (Snipes, 1968) which in turn could be related to changes in membrane properties.

Dietary lipids are also known to modulate membrane structure and functions (Christon et al, 1988a; McMurchie, 1988), especially those related to nutrient absorption (Thomson et al, 1986; Brasitus et al, 1989).

This experiment was undertaken to study the effects of a low linoleate diet on both the lipid composition of the enterocyte brush border membrane and the morphology of the rat small intestinal mucosa in an attempt to better understand their putative relationships.

\section{MATERIALS AND METHODS}

\section{Dietary conditions}

Twelve female Wistar rats were divided into 2 homogeneous groups after weaning (at $3 \mathrm{wk}$ of age). For 19 wk they were fed isoenergetic semisynthetic diets containing $5 \%$ of either corn oil for one group (control), or hydrogenated coco- nut oil for the other group (low lineoleate "low lin") and differing only in their fatty acid composition (Christon et al, 1988a). The control diet contained $27.4 \mathrm{~g}$ linoleic acid $(18: 2 \mathrm{n}-6)$ and $0,9 \mathrm{~g} \alpha-$ linolenic acid (18:3n-3)/1000 $\mathrm{g}$ of diet, while the low lin diet was a highly saturated lipid diet containing only $2.6 \mathrm{~g} 18: 2 \mathrm{n}-6 / 1000 \mathrm{~g}$ of diet and an undetected level of $\alpha$-linoleic acid (table I). Feed and water were provided ad libitum. At the end of the experimental period, rats were killed by decapitation after light anesthesia with diethy! ether.

\section{Histological techniques}

Samples of jejunum (mid small intestine) and ileum $(5 \mathrm{~cm}$ before the caecum) were quickly removed for morphometrical studies. Ligated segments $\approx 2 \mathrm{~cm}$ long were prefixed by injection of Carnoy fixative into the gut lumen, postfixed by immersion in the same fixative for $12 \mathrm{~h}$, then dehydrated and embedded in paraffin. Sections (5

Table I. Fatty acid composition $(\%, w / w)$ of dietary lipids.

Fatty acids ${ }^{1} \quad$ Control Low lin

$\begin{array}{lrr}8: 0 & - & 1.2 \\ 10: 0 & - & 7.9 \\ 12: 0 & - & 46.5 \\ 14: 0 & - & 17.0 \\ 16: 0 & 12.4 & 8.2 \\ 16: 1 n-7 & 1.1 & - \\ 18: 0 & 3.1 & 7.2 \\ 18: 1 n-9 & 27.7 & 6.8 \\ 18: 2 n-6 & 54.7 & 5.1 \\ 18: 3 n-3 & 1.7 & - \\ & & \\ \text { Saturated } & 15.5 & 88.0 \\ \text { Monounsaturated } & 28.8 & 6.8 \\ \text { Polyunsaturated } & 56.4 & 5.1\end{array}$

\footnotetext{
${ }^{1}$ Fatty acids were designated by the number of carbon atoms followed by the number of double bonds. The position of the first double bond relative to the methyl (n) end of the molecule was also indicated. Fatty acids contributing for $<1 \%$ were omitted.
} 
$\mathrm{mm}$ ) were stained with hemaluneosin. The villus length and crypt depth were recorded using an ocular micrometer. Only villi sectioned from their base to the top, with a single epithelial layer at their tip and crypts with visible lumen along their entire depth were considered. Measurements were made on at least 10 villi and associated crypts.

$1-\mathrm{cm}$ long ligated segments, adjacent to those obtained for light microscopy were prefixed by injection into the gut lumen of $2.5 \%$ glutaraldehyde in a $0.1 \mathrm{M}$ sodium cacodylate buffer, $335 \mathrm{mOsm}, \mathrm{pH}$ 7.6. They were then cut into very small pieces in the same fixative. These slices were washed in $0.15 \mathrm{M}$ sodium cacodylate buffer, postfixed in $2 \%$ osmium tetroxide overnight, dehydrated and embedded in Epon 812 with flat moulds of silicone rubber. They were oriented using a binocular dissecting microscope.

Semi-thin sections ( $\approx 10$ per group) of the specimen blocks gave an overall view of the mucosa. These blocks were retrimmed with an LKB pyramitome equipped with a target marker to obtain a mesa by trimming away all the crypts and the enterocytes situated at the base and at the top of the villus. Therefore, only the enterocytes located at mid-villus position were examined.

Ultra-thin sections were contrasted with lead citrate and uranyl acetate, then observed on a Zeiss EM 10 transmission electron microscope, at an accelerating voltage of $80 \mathrm{kV}$. Mean length of microvilli was obtained as previously reported (Meslin and Sacquet, 1984) from measurements (100 per intestinal division in each group) from the bottom to the apex on 50 electron micrographs ( $x 32$ 000). Mitochondria and Golgi apparatus were also observed on the same electron micrographs.

At the same anatomical sites, samples of $\approx 1$ $\mathrm{cm}^{2}$ were prefixed with gultaraldehyde, postfixed with osmium tetroxide, and critical-point-dried using freon. The samples were gold-metallized and observed on a Hitachi S 450 (Elexience, Verrières le Buisson, France) scanning electron microscope.

\section{Membrane preparation and lipid composition}

The rat small intestine was rapidly removed, rinsed with cold saline and the mucosa scraped with a glass slide. Purified brush border membrane vesicles were then obtained by the $\mathrm{Ca}^{2+}$ precipitation method of Schmitz et al (1973), modified by Kessler et al (1978). 200- $\mu$ l aliquots were stored under liquid nitrogen until analysis. The purity of BBM vesicles was routinely checked by determination of the specific activity of the marker enzyme sucrase (Dahlqvist, 1964). The final BBM fraction showed a 22-fold enrichment in sucrase specific activity with respect to the original homogenate. Protein was determined according to Lowry ot al (1951) using bovine serum albumin as a standard. No difference in relative membrane purity or in protein content (mean $3.5 \mathrm{mg} / \mathrm{g}$ of mucosa) was noted between control and low lin rats.

Lipid composition of intestinal BBM was determined as previously described (Christon et al, 1988a). After extraction of the total lipids using chloroform/methanol $(2: 1, v / v)$ solvent containing $0.01 \%(w / v)$ butylated hydroxytoluene (Folch et al, 1957), neutral lipids, glycolipids and phospholipids were separated by a Sep-Pak method (Juaneda and Rocquelin, 1985). Cholesterol was assessed from the neutral lipid fraction by an enzymatic method (Boehringer Mannheim, test kit). Phospholipid classes were separated by high-performance liquid chromatography (Beckman Instruments, Gagny, France); their purity was verified using thin-layer chromatography and quantitative estimation was carried out by inorganic phosphorus determination. Total phospholipids were then transmethylated (Berry et al, 1965) and the fatty acid methyl esters obtained were analyzed using a Packard model 427 gas chromatograph (Packard, Rungis, France) equipped with a flame ionization detector and a CP Wax 52 CB bonded fused silica capillary column (50 $\mathrm{m} \times 0.2 \mathrm{~mm}$ (D). Peaks were identified by comparison of equivalent chain lengths with those of authentic fatty acid methyl esters. Automatic expression of data was performed by a microcomputer coupled with a Delsi (Enica 10) integrator (Delsi Instruments, Suresnes, France).

\section{Statistical analysis}

Data were submitted to analysis of variance and the comparisons between groups were made using Student's $t$-test (Snedecor and Cochran, 1972). Values were expressed as means \pm SEM. 


\section{RESULTS}

As previously observed with the same experimental conditions (Christon et al, 1988a), final body weight was similar for control and low lin rats: $238.7 \pm 8.3 \mathrm{~g}$ and $238.8 \pm 6.2 \mathrm{~g}$, respectively.

\section{Mucosal morphometry}

As compared to the control diet, the low linoleate diet was associated in the jejunum with similar villus height and lower crypt depth (table II). In the ileum, both villus height and crypt depth decreased following the dietary treatment.

Figure 1 illustrates the measured lengths of the enterocyte microvilli. They were significantly higher in low lin than in control rats in the jejunum $(P<0.01)$ as well as the ileum $(P<0.05)$.

\section{Electron microscopy}

Scanning electron micrographs of the mucosal surface of the jejunal and ileal tissues are shown in figures 2 and 3, respectively. At both intestinal sites, low lin rat

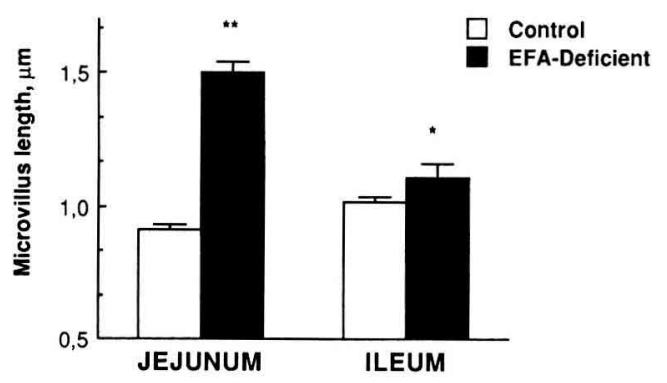

Fig 1. Length of the enterocyte microvilli $(\mu \mathrm{m})$ in the jejunum and ileum of control (D) and low lin $(\square)$ rats. Stars indicate differences from control: " $P<0.05 ;$;* $P<0.001$.

mucosa exhibited wider intervillous spaces than in controls, associated with irregular villous contour. This phenomenon was more pronounced in the ileum.

As compared to that of controls, some striking differences were found in epithelial cell appearance (fig 4). Their mitochondria particularly showed a decreased number of cristae which appeared to be clear. Also the Golgi apparatus was often dilated. Microvilli (not shown) did not exhibit any structural change with EFA deficiency, apart from an apparent increased length in the jejunum.

Table II. Morphometric measurements of small intestine mucosal structure in control and low lin rats ${ }^{1}$.

\begin{tabular}{lrrrr}
\hline & \multicolumn{2}{c}{ Jejunum } & \multicolumn{2}{c}{ lleum } \\
& Control & Low lin & Control & Low lin \\
\hline Crypt depth $(\mu \mathrm{m})$ & $89 \pm 2^{\mathrm{a}}$ & $64 \pm 1^{\mathrm{b}}$ & $80 \pm 2^{\mathrm{c}}$ & $61 \pm 1^{\mathrm{b}}$ \\
Villus height $(\mu \mathrm{m})$ & $312 \pm 5^{\mathrm{a}}$ & $302 \pm 5^{\mathrm{a}}$ & $274 \pm 8^{\mathrm{b}}$ & $232 \pm 6^{\mathrm{c}}$ \\
\hline
\end{tabular}

\footnotetext{
1 Data are means \pm SEM for 20 determinations. Values in the same row not sharing a common superscript letter were significantly different $(P<0.01)$. There was a significant interaction $(P<0.05)$ for villus height between intestinal sites and dietary treatments.
} 


\section{Lipid composition of enterocyte luminal membrane}

As shown in table III, the intestinal BBM vesicle phospholipid and cholesterol contents relative to proteins as well as the CHOL/PL ratio were not modified by the dietary treatment. The amounts of the different classes of membrane constitutive phospholipids (fig 5) were also identical in the 2 groups. They consisted mainly of phosphatidylcholine (PC) and phosphatidylethanolamine (PE) classes, for $\approx 32 \%$ each, with phosphatidylserine (PS), phosphatidylinositol (PI) and sphingomyelin (SM) classes constituting $15,7.5$ and $8 \%$, respectively. However, the fatty acid composition of BBM phospholipids (table IV) was markedly affected by the low lin diet. Saturated fatty acid (SFA) levels were not significantly changed, whereas linoleic, arachidonic and most polyunsaturated fatty acid (PUFA) levels decreased. Conversely, palmitoleic, oleic and particularly 5, 8, 11-eicosatrienoic acid levels significantly increased. Consequently, the unsaturation index, estimated as the double bond index (DBI)/SFA ratio, was not modified while the $16: 1 n-7 / 16: 0,18: 1 n-9 / 18: 0$ and $20: 4 n-6 / 18: 2 n-6$ ratios increased $(P<$ 0.01 ) in EFA-deficient as compared to con-

Table III. Phospholipid and cholesterol contents of rat intestinal BBM vesicles ${ }^{1}$.

\begin{tabular}{lll}
\hline & Control & Low lin \\
\hline & & \\
Phospholipids (PL) & $287 \pm 8$ & $328 \pm 59$ \\
Cholesterol (CHOL) & $165 \pm 18$ & $124 \pm 31$ \\
CHOL/PL, mol/mol & $0.58 \pm 0.05$ & $0.54 \pm 0.09$ \\
\hline
\end{tabular}

${ }^{1}$ Data (nmol/mg protein) are means \pm SEM. There was no significant difference $(P>0.05)$ due to dietary treatment. trol rat BBM. The triene $(20: 3 n-9) /$ tetraene $(20: 4 n-6)$ ratio was also higher $(P<0.01)$ in the former, showing the classic pattern

Table IV. Fatty acid composition (mol \%) of rat intestinal BBM phospholipids ${ }^{1}$.

\begin{tabular}{|c|c|c|c|}
\hline Fatty acid & Control & Low lin & \\
\hline $\begin{array}{l}16: 00 \\
18: 00 \\
20: 00 \\
22: 00 \\
24: 00\end{array}$ & $\begin{array}{r}23.4 \pm 2.5 \\
30.7 \pm 0.6 \\
1.0 \pm 0.2 \\
0.9 \pm 0.2 \\
0.8 \pm 0.1\end{array}$ & $\begin{array}{r}23.8 \pm 0.5 \\
24.5 \pm 0.7 \\
0.7 \pm 0.0 \\
0.5 \pm 0.0 \\
0.6 \pm 0.1\end{array}$ & $*$ \\
\hline$\Sigma$ SFA & $58.0 \pm 2.6$ & $52.7 \pm 4.0$ & \\
\hline $\begin{array}{l}16: 1 n-7 \\
18: 1 n-7 \\
16: 1 n-9 \\
18: 1 n-9 \\
20: 1 n-9 \\
24: 1 n-9\end{array}$ & $\begin{array}{l}0.9 \pm 0.2 \\
1.4 \pm 0.0 \\
1.2 \pm 0.3 \\
7.7 \pm 1.4 \\
0.4 \pm 0.0 \\
0.2 \pm 0.0\end{array}$ & $\begin{array}{r}2.4 \pm 0.3 \\
2.8 \pm 0.2 \\
2.6 \pm 0.0 \\
17.8 \pm 0.1 \\
0.5 \pm 0.0 \\
0.4 \pm 0.1\end{array}$ & $\begin{array}{l}* \\
* \\
* \\
* \\
* \\
*\end{array}$ \\
\hline $20: 3 n-9$ & $0.1 \pm 0.0$ & $12.1 \pm 0.1$ & $\star \star$ \\
\hline $\begin{array}{l}\sum \text { MUFA } \\
\sum n-9+n-7\end{array}$ & $\begin{array}{l}11.6 \pm 1.9 \\
11.8 \pm 1.9\end{array}$ & $\begin{array}{l}26.6 \pm 0.2 \\
38.6 \pm 0.1\end{array}$ & $* *$ \\
\hline $\begin{array}{l}18: 2 n-6 \\
18: 3 n-6 \\
20: 3 n-6 \\
20: 4 n-6 \\
22: 4 n-6 \\
22: 5 n-6\end{array}$ & $\begin{array}{r}8.4 \pm 0.6 \\
0.2 \pm 0.1 \\
0.6 \pm 0.3 \\
17.9 \pm 2.9 \\
1.1 \pm 0.9 \\
1.3 \pm 0.0\end{array}$ & $\begin{array}{l}2.0 \pm 0.1 \\
0.0 \pm 0.0 \\
0.2 \pm 0.0 \\
7.1 \pm 0.5 \\
0.2 \pm 0.0 \\
0.3 \pm 0.2\end{array}$ & $\begin{array}{l}* * \\
* \\
* \\
*\end{array}$ \\
\hline$\sum n-6$ & $29.4 \pm 4.6$ & $9.8 \pm 0.2$ & $* *$ \\
\hline $\begin{array}{l}20: 5 n-3 \\
22: 6 n-3\end{array}$ & $\begin{array}{l}0.1 \pm 0.1 \\
0.8 \pm 0.0\end{array}$ & $\begin{array}{l}0.3 \pm 0.0 \\
0.6 \pm 0.0\end{array}$ & * \\
\hline $\begin{array}{l}\sum n-3 \\
\sum \text { PUFA }\end{array}$ & $\begin{array}{r}0.8 \pm 0.0 \\
30.4 \pm 4.6\end{array}$ & $\begin{array}{r}0.9 \pm 0.1 \\
22.8 \pm 0.2\end{array}$ & * \\
\hline $\begin{array}{l}\text { DBI/SFA } \\
20: 3 n-9 / 20: 4 n-6\end{array}$ & $\begin{array}{l}2.1 \pm 0.4 \\
0.0 \pm 0.0\end{array}$ & $\begin{array}{l}2.0 \pm 0.0 \\
1.7 \pm 0.1\end{array}$ & ** \\
\hline
\end{tabular}

\footnotetext{
1 Fatty acids are designated as in table !. Values are means \pm SEM for 6 rats. Significant differences from control are indicated as: ${ }^{*}, P<0.05$ or ${ }^{* *}, P<0.01$. SFA, saturated fatty acids; MUFA, monounsaturated fatty acids; PUFA, polyunsaturated fatty acids; DBI: double bond index $=\Sigma$ (mol\% each unsaturated fatty acid * number of double bonds of the same fatty acid); DBI/SFA: unsaturation index.
} 


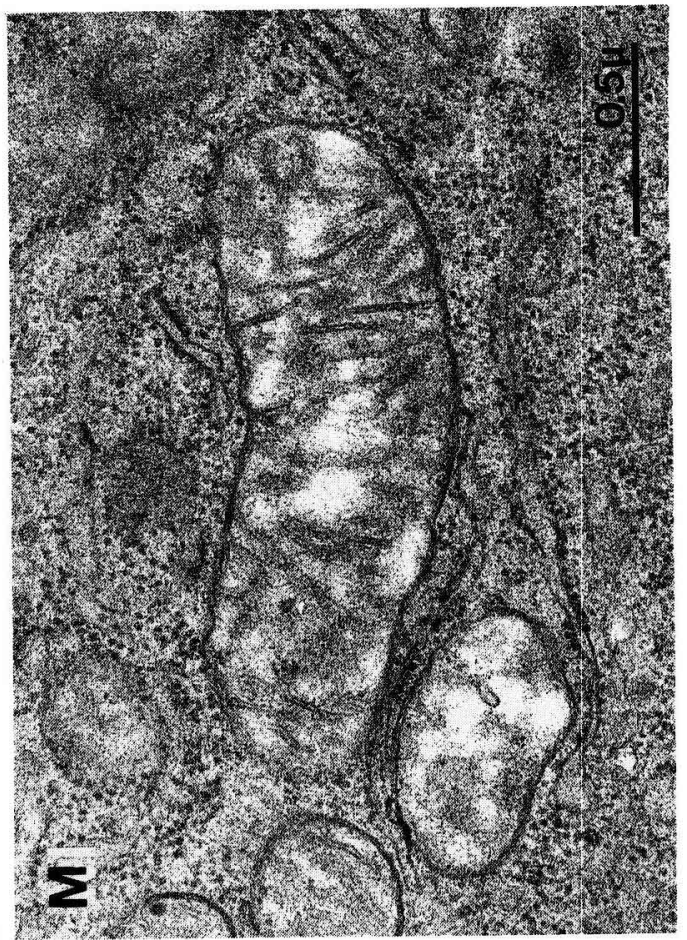

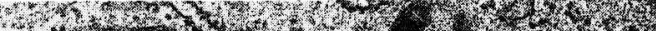
s.t.

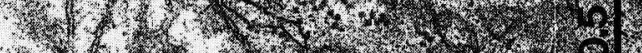

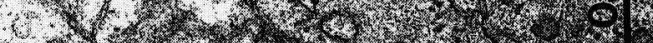
r.

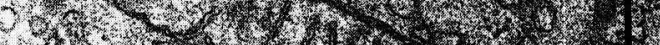

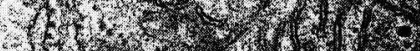
[3]

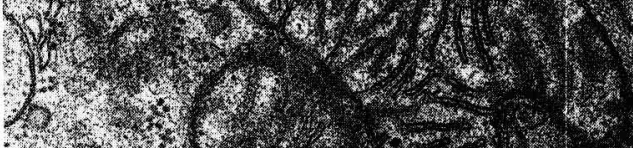

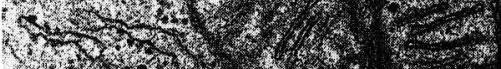

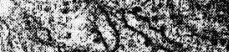

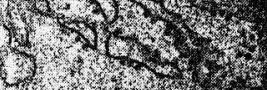

3.t.

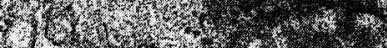

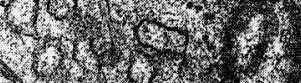

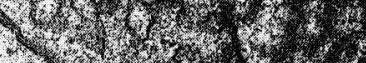

3.t.

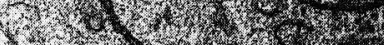

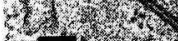

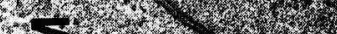

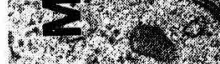

f.r.t.

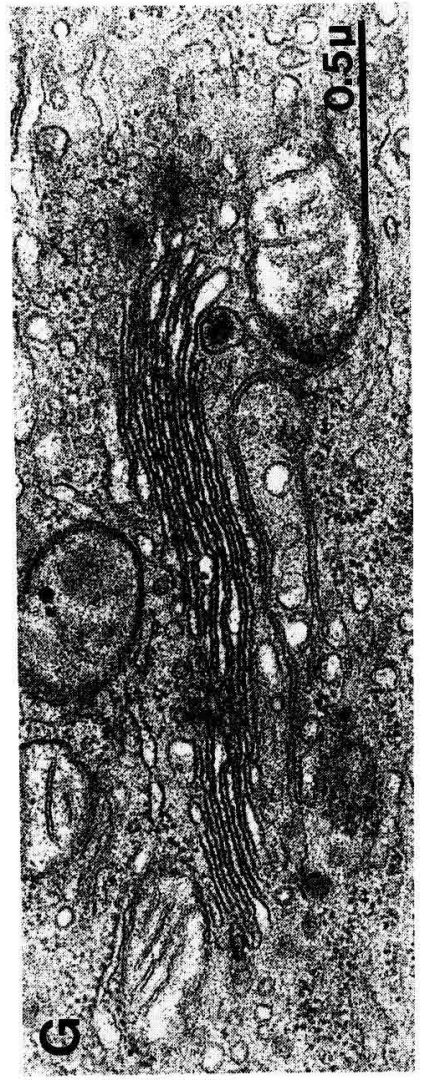

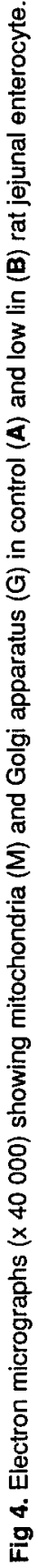

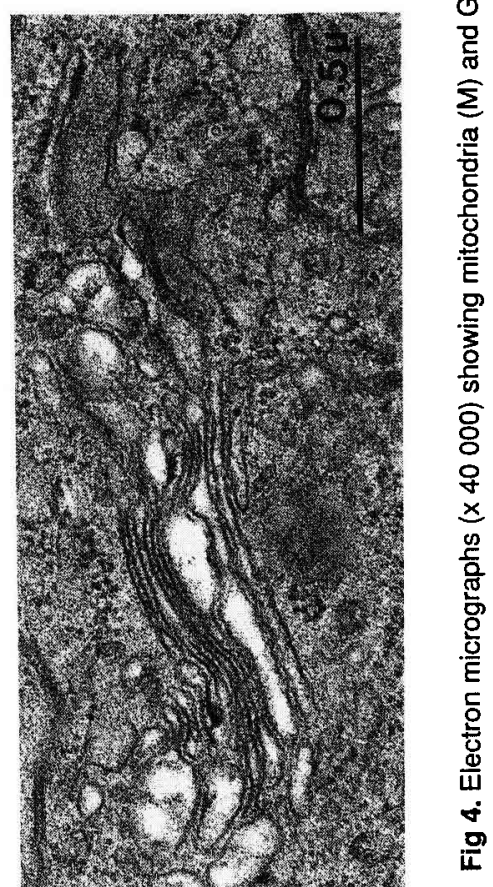




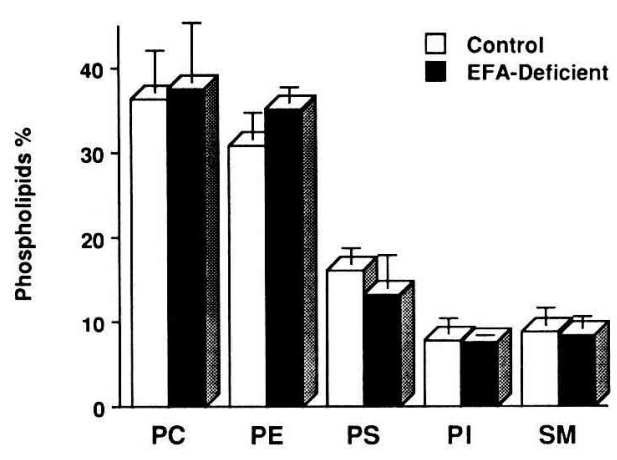

Fig 5. Phospholipid class distribution in control (D) and low lin (口) rat BBM. PC, phosphatidylcholine; PE, phosphatidylethanolamine; PI, phosphatidylinositol; PS, phosphatidylserine; SM, sphingomyelin.

of an EFA deficiency following nutritional treatment (Holman, 1960).

\section{DISCUSSION AND CONCLUSION}

The present results clearly show that an insufficient dietary EFA level significantly altered both intestinal mucosal morphology according to Snipes $(1967 a, 1968)$ and intestinal BBM lipid composition, confirming previous experiments in the rat (Brasitus et al, 1985; Christon et al, 1988b).

Morphometric measurements showed a decreased size of crypt-villus axis in the jejunum as well as in the ileum of low lin animals as compared to controls. However, according to Thomson et al (1986), low lin rats had significantly lower villus height than controls only in the ileum, whereas crypt depth was shorter whatever the intestinal site. Although the meaning of such an observation is unclear, it could result from a more prolonged effect of such a dietary treatment in our experiment (22 wk) than in others, for instance that of
Snipes (12 wk) or Thomson et al (2-3wk). The apparently abraded tips of the villi shown by the scanning electron micrographs evoked an increased rate of enterocyte extrusion as has been observed in EFA-deficient mice (Snipes, 1967b). Using an radioautography technique with ${ }^{3} \mathrm{H}$ thymidine, this author also demonstrated that migration rate of EFA-deficient epithelial cells from the crypts to the tips of the villi was twice that of either control, ie 1.5 days vs 3 days, respectively. There seems to be an equilibrium between cell production rate and crypt-villus size which appeared to be sensitive to dietary modulation (Syme and Smith, 1982). Furthermore, both morphometric measurements and scanning electron micrographs strongly suggest that, in the ileum, the modest reduction in villus height associated with a slight increase in microvillus length likely led to no change in the mucosal surface area, whereas in the jejunum, the unchanged villus height but markedly increased microvillus length indicate a possible increase in the absorptive surface area of the EFA-deficient animals. Nevertheless, a decreased fat absorption has been noted in such a nutritional condition (Snipes, 1968). Therefore, as absorption takes place mainly in the upper part of the villus (Borgström et al, 1957) and although no measurement of cellular kinetics was made here, this could rather be related to a reduced life span of the enterocyte, limiting its capacity to transport nutrients (Dauncey et al, 1983). The above structural modifications reveal a disturbed regulation of the normal development of the intestinal mucosa by the nutritional treatment. Numerous studies dealing with cell proliferation in this tissue have demonstrated a predominant influence of prostaglandins (PG) of the $E$ and $F$ series (Dembinski and Konturek, 1985). It has recently been shown that the hyperplasia due to $P G E_{2}$ in rat small intestinal epithelium 
starts in the villi and is initiated by reduced cell exfoliation from the villous tips. In fact, oral administration of $P G E_{2}$ was followed by increased cellularity of the jejunal villi and not of the crypts (Uribe and Johansson, 1988). It has also been demonstrated that dietary EFA deficiency led to reduced PG synthesis by platelets (Parnham et al, 1979) and by the whole body (Hansen and Jensen, 1985; Ferreti et al, 1989). Furthermore, modified fatty acid composition as observed in low lin rat BBM phospholipids has been previously associated with a decrease in membrane fluidity (Brasitus et al, 1985; Christon et al, 1988b). In these conditions, membrane-bound phospholipase $A_{2} \quad\left(P L A_{2}\right)$ activity towards endogenous phospholipids might decrease, as shown in rat liver (Koumanov and MomchilovaPankova, 1989) and thereafter the availability of arachidonic acid substrate for $P G$ $E_{2}$ synthesis might be reduced (Hansen and Jensen, 1985; Heisler, 1989). Hence, we may speculate than, in agreement with Hart et al (1988), the morphological changes exhibited by the low lin rat small intestine in this study could be explained by a lower production of $P G E_{2}$ than in controls, caused by the decreased level of its precursor (Hwang et al, 1975; Lefkowith et al, 1986).

Moreover, the decreased absorption observed in the EFA-deficient animals (Snipes, 1968) could also be partly linked to the altered BBM composition, as it was shown that modified membrane PUFA composition may induce significant changes in membrane functional properties (Stubbs and Smith, 1984). Comparable observations were made in the intestinal microvillus membrane of EFA-deficient rats (Thomson et al, 1988; Brasitus et al, 1989). Confirming our previous findings in rat BBM (Christon et al, 1988b), cholesterol and phospholipid contents, CHOL/PL molar ratio and phospholipid class distribution remain quite unchanged with the low lin diet. Therefore, only the fatty acid composition of phospholipids could be involved in a modified membrane protein activity (Burns and Spector, 1987; McMurchie, 1988). These compositional changes lead to a new spatial arrangement of double bonds in the phospholipid matrix, due to the replacement of EFA series acyl chains (mainly $n-6$ fatty acids) by $n-7$ and $n-9$ fatty acids (monounsaturated fatty acidsMUFA-and eicosatrienoic acid) in the low lin rat BBM. This probably accounts for alteration in the molecular interactions within the membrane (Christon et al, 1989) and therefore may modify membrane-bound protein activities.

Although no direct evidence has been provided by the present data, a decreased functionality of the low lin rat enterocytes could also partly be connected with some structural changes in the mitochondria and Golgi apparatus. The mitochondria are known to be very sensitive to dietary lipids (Smithson, 1967; Innis and Clandinin, 1981) while the latter organelle has been shown to exhibit altered membrane fluidity in the case of EFA deficiency (Brasitus et al, 1988).

In conclusion, an unbalanced and insufficient dietary level of EFA significantly altered mucosal morphology and brush border membrane structural properties. Under our conditions (mainly using linoleic and arachidonic acids), it may be concluded that as regards their structural and dynamic aspects, EFA might be one of the major factors in determining optimal morphology and functional capacity of the epithelial cell membrane in the rat small intestine.

\section{ACKNOWLEDGMENTS}

We wish to thank $M$ Sérézat, $P$ Dahirel and $A$ Gondouin for technical and secretarial assistance, and A Bouroche for the English corrections. 


\section{REFERENCES}

Berry JF, Cevalos WH, Wade RR (1965) Lipid class and fatty acid composition of intact peripheral nerve and during Wallerian degeneration. J Am Oil Chem Soc 42, 492-500

Borgström B, Dahlqvist A, Lundh G, Sjovall J (1957) Studies of intestinal digestion and absorption in the human. $J$ Clin Invest 36 , 1521-1536

Brasitus TA, Davidson NO, Schachter D (1985) Variations in dietary triacylglycerol saturation alter the lipid composition and fluidity of rat intestinal plasma membranes. Biochim Biophys Acta 812, 460-472

Brasitus TA, Dahiya R, Dudeja PK (1988) Rat proximal small intestinal Golgi membranes: lipid composition and fluidity. Biochim Biophys Acta 958, 218-226

Brasitus TA, Dudeja PK, Bolt MJG, Sitrin MD, Baum C (1989) Dietary trialglycerol modulates sodium-dependent D-glucose transport, fluidity and fatty acid composition of rat small intestinal brush border membrane. Biochim Biophys Acta 979, 177-186

Burns CP, Spector AA (1987) Membrane fatty acid modification in tumor cells: a potential therapeutic adjunct. Lipids 22, 178-184

Christon R, Fernandez Y, Cambon-Gros C, Périquet $A$, Deltour $P$, Léger $C L$, Mitjavila $S$ (1988a) The effect of dietary essential fatty acid deficiency on the composition and properties of the liver microsomal membrane of rats. J Nutr 118, 1311-1318

Christon R, Even V, Daveloose D, Viret J, Linard A, Thévenoux J, Léger CL (1988b) Influence de la carence en acides gras polyinsaturés essentiels (AGPE) sur la composition et la structure dynamique de la membrane microvilleuse entérocytaire (MMVE) chez le rat. Reprod Nutr Dev 28, 657-658

Christon R, Even V, Daveloose D, Léger CL, Viret $J$ (1989) Modification of fluidity and lipidprotein relationships in pig intestinal brush border membrane by dietary essential fatty acid deficiency. Biochim Biophys Acta 980, 77-84

Dahlqvist A (1964) Method for assay of intestinal disaccharidases. Anal Biochem 7, 18-25

Dauncey MJ, Ingram DL, James PS, Smith MW (1983) Modification by diet and environmen- tal temperature of enterocyte function in piglet intestine. J Physio/ 341, 441-452

Dembinski A, Konturek SJ (1985) Effects of E, F and I series prostaglandins and analogues on growth of gastroduodenal mucosa and pancreas. Am J Physiol 248 (Gastrointest Liver Physiol 11), G170-G175

Eynard AR, Monis B, Kalinec F, Leguizamon RO (1982) Increased proliferation of the epithelium of the proximal alimentary tract of EFA-deficient rats: a light and electron microscopy study. Exp Mol Pathol 36, 135-143

Ferreti A, Judd JT, Taylor PR, Schatzkin A, Brown C (1989) Modulating influence of dietary lipid intake on the prostaglandin system in adult men. Lipids 24, 419-422

Folch J, Lees M, Sloane-Stanley GH (1957) A simple method for the isolation and purification of total lipids from animal tissues. $J$ Biol Chem 226, 497-509

Hansen HS, Jensen B (1985) The effect of a single oral dose of ethyl linoleate on urinary prostaglandin $E_{2}$ excretion in essential fatty acid-deficient rats. J Nutr 115, 39-44

Hart MH, Grandjean CJ, Park JHY, Erdmann SH, Danderhoof JOA (1988) Essential fatty acid deficiency and postresection mucosal adaptation in the rat. Gastroenterology 94 , 682-687

Heisler $S$ (1989) Phospholipase $A_{2}$ activation by melittin causes amylase release from exocrine pancreas. Can J Physiol Pharmacol 67, 411-416

Holman RT (1960) The ratio of trienoic: tetraenoic acids in tissue lipids as a measure of essential fatty acid requirement. $J$ Nutr 70 , 405-410

Hwang DH, Mathias MM, Dupont J, Meyer DL (1975) Linoleate enrichment of diet and prostaglandin metabolism in rats. $J$ Nutr 105 , 995-1002

Innis SM, Clandinin MT (1981) Dynamic modulation of mitochondrial membrane physical properties and ATPase activity by diet lipid. Biochem J 198, 167-175

Juaneda P, Rocquelin G (1985) Rapid and convenient separation of phospholipids and non phosphorus lipids from rat heat using silica cartridges. Lipids 20, 40-41

Kessler , Acuto O, Storelli C, Murer H, Müller M, Semenza G (1978) A modified procedure for 
the rapid preparation of efficiently transporting vesicles from small intestinal brush border membranes. Their use in investigating some properties of D-glucose and choline transport systems. Biochim Biophys Acta 506, 136-154

Koumanov KS, Momchilova-Pankova AB (1989) Effect of lipid environment on membrane phospholipase $\mathrm{A}_{2}$ activity. In: Biomembranes and Nutrition - Nutrients Affecting Lipid Composition and Properties of Cell Membranes (Léger CL, Béréziat G, eds) Coll INSERM, Paris, 229-238

Lefkowith JB, Sprecher H, Needleman P (1986) The role and manipulation of eicosanoids in essential fatty acid deficiency. Prog Lipid Res 25, 111-117

Lowry OH, Rosebrough NJ, Farr AL, Randall RJ (1951) Protein measurement with the folin phenol reagent. J Biol Chem 193, 265-275

Meslin JC, Sacquet E (1984) Effects of microflora on the dimensions of enterocyte microvilli in the rat. Reprod Nutr Dev 24, 307-314

McMurchie EJ (1988) Dietary lipids and regulation of membrane fluidity and function. In: $A d-$ vances in Membrane Fluidity, Vol 3. Physiological Regulation of Membrane Fluidity (Aloia RC, Curtain CC, Gordon LM, eds) AR Liss Inc, NY, 189-237

Parnham MJ, Vincent JE, Zijlstra FJ, Bonta IL (1979) The use of essential fatty aciddeficient rats to study pathophysiological roles of prostaglandins. Comparison of prostaglandin production with some parameters of deficiency. Lipids 14, 407-412

Schmitz J, Preiser H, Maestracci D, Gosh BK, Cerda JJ, Crane RK (1973) Purification of the human intestinal brush border membrane. Biochim Biophys Acta 323, 98-112

Smithson JE (1967) The effect of essential fatty acid deficiency on liver mitrochondria of the rat and mouse. Structural and functional alterations. PhD Thesis Health Sci (Pathology),
Brown University, Providence, Rhode Island

Snedecor GW, Cochran WG (1972) Statistical Methods. lowa State Univ Press, Ames, IA, 6 th edn

Snipes RL (1967a) The effect of essential fatty acid deficiency on the jejunal epithelium of the rat and mouse. Structural and functional alterations. PhD Thesis Health Sci (Pathology), Brown University, Providence, Rhode Island, $196 \mathrm{pp}$

Snipes RL (1967b) Cellular dynamics in the jejunum of essential fatty acid deficient mice. Anat Rec 159, 421-430

Snipes RL (1968) The effects of essential fatty acid deficiency on the ultrastructure and functional capacity of the jejunal epithelium. Lab Invest 18, 179-189

Stubbs CD, Smith AD (1984) The modification of mammalian membrane polyunsaturated fatty acid composition in relation to membrane fluidity and function. Biochim Biophys Acta 779, 89-137

Syme G, Smith MW (1982) Intestinal adaptation to protein deficiency. Cell Biol Int Rep 6, 573578

Thomson ABR, Keelan M, Clandinin MT, Walker $K$ (1986) Dietary fat selectively alters transport properties of rat jejunum. $J$ Clin Invest $77,279-288$

Thomson ABR, Keelan M, Garg ML, Clandinin MT (1988) Dietary effects of w3-fatty acids on intestinal transport function. Can J Physiol Pharmacol 66, 985-992

Uribe A, Johansson C (1988) Initial kinetic changes of prostaglandin $E_{2}$-induced hyperplasia of the rat small intestinal epithelium occur in the villous compartments. Gastroenterology 4, 1335-1342

Yurkowski M, Walkers BL (1970) Lipids of the intestinal mucosa of normal and essential fatty acid deficient rats. Can J Physiol Pharmacol $48,631-639$ 